„Etnografia Polska”, t. LXIV, 2020, z. 1-2

PL ISSN 0071-1861; e-ISSN: 2719-6534

DOI: $10.23858 / E P 64.2020 .003$

CC BY 4.0

MARCJANNA NÓŻKA

Instytut Socjologii UJ, Kraków

\title{
POSTAWY WOBEC ZAMIESZKIWANEJ PRZESTRZENI \\ I MOBILNOŚĆ MIESZKAŃCÓW MIEJSKICH ENKLAW BIEDY W POLSCE
}

\section{WPROWADZENIE}

Zróżnicowane formy przemieszczania się, przyczyny i przejawy zablokowanego ruchu i nieruchliwości oraz wynikająca z nich złożoność zjawisk kulturowych i społecznych to tematyka badań coraz chętniej podejmowana przez antropologów i socjologów (np. Pawlak 2015; Rogowski 2018; Sheller 2017; Urry 2007). W kontekście dostrzeżonych potencjałów badania (nie)mobilności ludzi w przestrzeni szczególnym obszarem eksploracji wydają się enklawy biedy - przestrzenie wykluczeń, które w społecznym odbiorze ograniczają, a nawet uniemożliwiają, szeroko rozumiany ruch. Wykluczenie z różnych sfer życia bywa powodowane i podtrzymywane m.in. brakiem lub niedostatkiem mobilności w przestrzeni fizycznej, cyfrowej, społecznej, kulturowej, edukacyjnej, gospodarczej (por. Kenyon 2006). Szczególną zaś uwagę zwraca się na systemy transportu i komunikacji, które stanowią techniczne zaplecze dla wielu rodzajów mobilności i lokowane są w centrum dynamiki współczesnego życia w mieście (Jirón, Lange, Bertrand 2010; Ureta 2008). Jednym z warunków inkluzji jest zatem mobilność powiązana z szerzej rozumianą dostępnością do określonych miejsc, ludzi i aktywności (Madanipour 2003; Stanley et al. 2011). Wyróżnia się co najmniej sześć wymiarów dostępności: fizyczny, finansowy, organizacyjny, czasowy, technologiczny, kompetencyjny (Cass, Shove, Urry 2005; Church, Frost, Sullivan 2000; Jirón, Lange, Bertrand 2010). W tym opracowaniu koncentruję się na wymiarze, który określam jako poznawczo-afektywny.

Pisząc o poznawczo-afektywnym wymiarze dostępności, mam na myśli wyobrażenia warunkujące mobilność i sposoby waloryzowania przestrzeni. Ta sama przestrzeń w przekonaniach i odczuciach jednych ludzi może być swojska i bezpieczna, chętnie zamieszkiwana lub odwiedzana, dla innych natomiast będzie obca, wroga, a przez to zwykle unikana, niechętnie przemierzana i eksplorowana. Poczucie wykluczenia oraz rzeczywisty brak partycypacji w różnych sferach życia mogą być zatem efektem nadanych przestrzeniom lingwistycznych dystynkcji (np. nazwanie jej slumsem lub gettem), przypisania jej negatywnych wartości i właściwości. Pozostająca w obiegu społecznym wiedza na temat tego rodzaju przestrzeni przez nie-mieszkańców zwykle nie jest potwierdzana w autopsji, ale w antycypowanym zagrożeniu 
i przezornym omijaniu takich okolic (por. Jargowsky, Steiner 1997). Społeczne naznaczenie przestrzeni może stać się piętnem jej lokatorów, wiązać się z przeniesieniem złej opinii o miejscu na jego mieszkańców. Przestrzeń może również zostać naznaczona przez zasiedlające ją osoby, gdy posiadają one - widoczne lub wiadome - społecznie nisko cenione cechy. Jak wynika z przeprowadzonych przeze mnie badań na obszarach miejskich enklaw biedy w Polsce, zamieszkujący je ludzie mają zróżnicowane postawy wobec tych przestrzeni, są świadomi negatywnych opinii na ich temat, ale nie zawsze je podzielają. Jakie zatem są ich wyobrażenia na temat zamieszkiwanych przestrzeni? Jakie mają wobec nich odczucia? Jak w kontekście tych wyobrażeń i odczuć przedstawia się ich przestrzenna mobilność? W artykule odpowiadam między innymi na te pytania, odwołując się do opracowanych przez uczestników moich badań rysunków i map szkicowych zamieszkiwanych okolic, ich wypowiedzi oraz zrealizowanych fotospacerów.

Zaznaczę, że mapowanie jako metoda badań obszarów biedy nie jest pomysłem nowym. Przykładowo, w XIX wieku Charles Booth stosował mapowanie - mapy kartograficzne - w celu wizualizacji zasięgu i dolegliwości biedy (za: Vaughan 2008). Mapowali przedstawiciele chicagowskiej szkoły ekologii społecznej (np. Burgess 1925). Również współcześnie w badaniach sfer wykluczenia i ubóstwa mapowanie uznawane jest za niezwykle użyteczne narzędzie. Sporządzane są zarówno kartograficzne mapy problemów na podstawie danych urzędowych (np. Czekaj 1999), jak i mapy wykorzystujące dane satelitarne (np. Steele et al. 2017). Eksplorowano także mapy mentalne i wyobrażenia mieszkańców slumsów, badając ich zachowania komunikacyjne (Karan, Bladen, Singh 1980). Natomiast za innowacyjne uznałam zastosowanie rysunków i map szkicowych, które - dzięki równoczesnemu odwołaniu się do wypowiedzi mieszkańców enklaw biedy na temat zasiedlonej i (nie)przemierzanej przez nich na co dzień okolicy - pozwoliły mi na ustalenie zmiennych różnicujących ich postawy wobec zamieszkiwanej przestrzeni. W artykule omawiam sześć takich postaw, które zidentyfikowałam, bazując na modelu inspirowanym wynikami badań empirycznych, etnologicznym opisem świata i antyświata Ludwika Stommy (2000) oraz wyróżnionymi przez Christiana Norberga-Schulza (1971) poziomami przestrzeni egzystencjalnej. Omówienie to stanowi konkluzję z wcześniej przedstawionej dyskusji nad wynikami badań. Poprzedza je opis założeń teoretycznych, źródeł danych empirycznych oraz prezentacja zebranego materiału uwzględniającego wyobrażenia enklaw biedy i ich waloryzację oraz mobilność uczestników badań, powiązaną z zamieszkiwaną przez nich przestrzenią: podwórkiem, najbliższą okolicą i miastem.

\section{ZAŁOŻENIA TEORETYCZNE}

Literatura poświęcona zgettoizowanym sąsiedztwom i enklawom biedy jest niezwykle zróżnicowana. Badane i analizowane są procesy wyłaniania oraz konstytuowania się takich enklaw, a także ich społeczno-przestrzenne usytuowanie względem pozostałych części miasta czy regionu (np. Ooi, Phua 2007; Warzywoda- 
-Kruszyńska, Jankowski 2013; Yuting, Fulong 2006). Podejmowane są zagadnienia związane z jakością ich infrastruktury, życiem codziennym mieszkańców, ich sytuacją rodzinną, zdrowotną, zawodową i ekonomiczną, sposobami radzenia sobie ze stresorami środowiskowymi (np. Bird, Montebruno, Regan 2017; Siddiqui, Pandey 2003; Warzywoda-Kruszyńska 1998). Dyskutowana jest sytuacja kobiet i los dzieci w tych przestrzeniach (np. Datta 2016; Ernst, Phillips, Duncan 2013; Potoczna, Warzywoda-Kruszyńska 2009), kwestie związane z realizacją praw człowieka i obywatela (np. Bennett 2018). Zbiorowości zamieszkujące enklawy biedy bywają opisywane w kontekście cech etnicznych i/lub klasowych, wyróżniających je spośród innych mieszkańców miasta (np. Walks, Bourne 2006). Równocześnie zaznaczę, że miejskie enklawy biedy w Polsce znacznie rzadziej nasuwają skojarzenia z wielokulturowością i etniczną różnorodnością ich mieszkańców. Poza enklawami zamieszkiwanymi przez społeczność romską (np. Zdulski 2011), te najczęściej zasiedlone są przez osoby niezróżnicowane pod względem etnicznym w stosunku do pozostałych mieszkańców miasta (np. Grotowska-Leder 2006). Jako obszar życia ludzi - a zarazem przedmiot badań - enklawy biedy mają zatem swoją społeczną, kulturową i geopolityczną specyfikę (np. Dupont et al. 2016; Sandhu 1987).

Tym, co wydaje się łączyć opisy enklaw biedy, jest nawarstwianie się na ich obszarze różnego rodzaju niedostatków, dewiacji i patologii (np. Jones 2010), gdzie problemy bezrobocia i przestępczości są zaostrzone. Natomiast zdaniem Maria L. Smalla (2015) skupianie się na deficytowych aspektach enklaw występuje tylko wówczas, gdy ich postrzeganie jest wąskie. Sprzyja temu fakt, że wokół tych przestrzeni narastało wiele mitów i uproszczonych narracji. Przykładowo powszechnie uznaje się je za miejsca kumulacji przestępczości, mimo że wyróżniający je silny system kontroli społecznej powoduje, że wskaźniki przestępczości bywają tam niskie. Poza tym pojęcie normy, jakim posługują się zewnętrzni obserwatorzy, pozostaje pod silnym wpływem tego, co mieści się w ich systemie wartości i głównym nurcie społecznym, pomijając kontekst, w którym obserwowane działania są realizowane. Nie zawsze też dostrzegane są $\mathrm{w}$ tych środowiskach potencjały, a w tym możliwości pojawiania się ruchów społecznych i przejawów solidarności nieznanych na bogatych obszarach miasta i przedmieściach (The Challenge of Slums... 2003).

Enklawy biedy stanowią nie tylko złożony, ale także ważny oraz trudny obszar eksploracji. Po pierwsze, faktem stało się zjawisko „urbanizacji biedy”. Na początku XXI wieku niemal 1 mld ludzi, czyli 32\% światowej populacji miejskiej, żył w slumsach. W 2003 roku prognozowano, że jeśli nie podejmie się żadnych działań zaradczych, w ciągu 30 lat liczba mieszkańców slumsów na świecie może się podwoić (Annan 2003). Enklawy biedy to zatem przestrzenie wymagające rozpoznania i interwencji. Poza tym społeczna i kulturowa niejednoznaczność tych obszarów, naznaczonych jako biednych, gorszych i niebezpiecznych, a także - kreowana przez te okoliczności - ich hermetyczność, niezmiennie budzą zainteresowanie badaczy, polityków, pracowników instytucji pomocowych i służb mundurowych, budzą także ciekawość, o czym świadczyć może zyskująca na popularności slum-turystyka (np. Frenzel et al. 2015). Po drugie, eksplorowanie enklaw nie jest etycznie obojętne. Ich 
badania wzbudzają kontrowersje, w tym zarzuty o szukanie sensacji i zarabianie na problemach biednych. Po trzecie, pozostające w obiegu społecznym stereotypy powodują, że ich wizerunek bywa upraszczany i generalizowany (Small 2015).

Uwzględniając złożoność okoliczności wpływających na rozumienie enklaw biedy i sposoby ich eksploracji, na potrzeby prowadzonych przeze mnie prac zawęziłam ich definicję do kilku wyróżniających je zmiennych: segregacji, przeludnienia, ubóstwa mieszkańców, zaniedbanych i społecznie izolowanych okolic (por. Davis 2006). To przestrzenie, w których się nie bywa, i takie, z których trudno wyjść. Przyczyniają się do tego co najmniej trzy okoliczności. Pierwsza z nich to zły stan infrastruktury transportowej i mieszkaniowej, brak inwestycji i odpowiedniej bazy ekonomicznej, czego konsekwencją są ograniczone możliwości mieszkańców, ich izolacja i bezrobocie. Po drugie, zamieszkiwanie enklaw biedy jest wynikiem segregacji, która oznacza koncentrację ludzi o najmniejszych możliwościach na obszarach o najsłabszym potencjale. Po trzecie, wspomniane okoliczności wpływają dewastująco na wizerunek miejsca i reputację jego mieszkańców (Lupton, Power 2002). Jako takie enklawy biedy uznawane są za kieszenie intensywnej deprywacji, wymagające interwencji, inwestycji i socjalnego wsparcia. Równocześnie są to przestrzenie identyfikacji (Nóżka 2016).

Rozumiane tak enklawy biedy, będące miejscem niezintegrowanym $\mathrm{z}$ sąsiednim i zarazem obcym dla ich mieszkańców światem zewnętrznym, mogą sprzyjać wytwarzaniu się kultury typu zamkniętego, podtrzymywanej przez głęboko zakorzenione i mityczne myślenie chroniące spójności własnego miejsca i sposobu życia (por. Łotman, Uspienski 1975). Wiąże się z tym wysoki stopień izolacji świadomościowej. Wyróżnia ją nieufność i dominacja przesądu w myśleniu o świecie, przekonanie, że poza granicami własnego, swojskiego świata, rozciąga się nieznany i budzący grozę świat obcych. Znajduje to wyraz w widzeniu świata w kategoriach opozycyjnych: orbis interior (nasz świat) - orbis exterior (świat na zewnątrz - antyświat). Obraz orbis interior jest pełną inwersją wizji orbis exterior, to, co w tym pierwszym jest głupie, w drugim staje się mądre i odwrotnie. Orbis interior jest sferą poznaną i użyteczną, rejonem topografii oswojonej. Atrybutami orbis exterior będą zatem nieużyteczność i obcość, łatwość utraty orientacji i pobłądzenia. Ten dychotomiczny sposób postrzegania rzeczywistości rzutuje na postawy i wybory w realnym życiu, znajduje też odbicie w preferencjach estetycznych. Pozytywna ocena walorów krajobrazu orbis interior równoznaczna jest $\mathrm{z}$ istnieniem przeciwstawnej opinii o pejzażach zewnętrznych. Orbis exterior jest nie tylko niewart poznania, dziki i nieużyteczny, ale i brzydki (Stomma 2000).

Zarysowana powyżej koncepcja świata i antyświata Ludwika Stommy, która wyrosła z badań wiejskiego, izolowanego środowiska z przełomu XIX i XX wieku, nie ogranicza się zdaniem jej autora do żadnego czasu, przestrzeni ani warstwy społecznej. Elementy izolacji świadomościowej odnajdujemy zarówno w kulturze XIX-wiecznej wsi, jak i we współczesnych zurbanizowanych społecznościach. Równocześnie obszary te są potencjalnie otwarte i dynamiczne. Stomma, zwracając uwagę na czynniki sprzyjające przełamywaniu izolacji świadomościowej podkreślał znaczenie w tym procesie szeroko rozumianej mobilności: poznawczej, intelektualnej, przestrzennej. 
W zależności od posiadanej wiedzy i doświadczeń, te same komponenty przestrzeni mogą być bowiem widziane w odmienny sposób przez różnych ludzi, którzy budują jej różne wizje (por. Nęcki 2004).

\section{ŹRÓDŁA DANYCH EMPIRYCZNYCH}

Zmierzając do rozpoznania postaw wobec zamieszkiwanej przestrzeni i mobilności mieszkańców enklaw biedy, odwołam się do wyników badań zrealizowanych przeze mnie wraz z zespołem w latach $2014-2016^{1}$ na terenie polskich enklaw zlokalizowanych w pobliżu miejskiego centrum, na obszarze dwóch miast (liczących powyżej 700 tysięcy mieszkańców). Teren eksploracji wybrałam, bazując na raportach z badań lokalnych, sprawozdaniach miejskich ośrodków pomocy społecznej oraz ogólnopolskich internetowych antyrankingach dzielnic, w których obszary te określano enklawami biedy. Wymieniano je jako przykłady obszarów zdegradowanych i niebezpiecznych, $\mathrm{z}$ nadreprezentacją lokali socjalnych oraz ubogich i bezrobotnych klientów pomocy społecznej. Nazwy tych miejsc zanonimizowałam ze względów etycznych. Uznałam, że ich ujawnienie nie ma istotnego znaczenia dla wyników badań, a może wzmacniać stygmatyzację mieszkańców.

Łącznie w badaniach wzięły udział 32 osoby - 16 mieszkańców z „pierwszej” enklawy biedy (8 kobiet, 8 mężczyzn) i 16 mieszkańców z „drugiej” (8 kobiet i 8 mężczyzn) - będące równocześnie lokatorami mieszkań socjalnych i klientami pomocy społecznej ze względów ekonomicznych. Osoby te były w wieku od 25 do 67 lat i miały polskie pochodzenie etniczne. $W$ analizach nie uwzględniam jednak płci i wieku badanych, brałam natomiast pod uwagę fakt zamieszkiwania przez nich wcześniej innego miejsca, zakładając, że inaczej wyobraża sobie i waloryzuje otoczenie ktoś z zewnątrz, a inaczej ten, kto jest jego stałym rezydentem (Tomaszewski 1984). Uczestnicy badań zamieszkiwali w danym miejscu od czterech do kilkudziesięciu lat. Niektórzy mieszkali tam przez całe swoje życie, inni w związku z wprowadzeniem się do partnera lub przyznaniem im przez gminę mieszkania socjalnego.

Trwające około półtorej godziny spotkanie odbywało się w mieszkaniu osób zrekrutowanych do badań i wiązało się ze spacerem po okolicy. Dobór próby był celowy i opierał się na dostępności potencjalnych uczestników badań. W rekrutacji wzięli udział znający środowisko pracownicy socjalni. Nawiązywali oni pierwszy kontakt z mieszkańcem, wyjaśniali cel badań i sposób ich realizacji, a następnie weryfikowali zgodę na spotkanie $\mathrm{z}$ osobą z zespołu badawczego. $\mathrm{W}$ ten sposób zabezpieczono prawo osób badanych do świadomego i dobrowolnego udziału w badaniach.

Zmierzając do ustalenia postaw uczestników badań wobec zamieszkiwanej przestrzeni, uwzględniłam ich trzy komponenty: wyobrażenia, wartościowanie przedmiotu postawy, zachowania (por. Smith 1947; Tesser, Shaffer 1990). Postawa to

\footnotetext{
${ }^{1}$ Projekt finansowany ze środków Narodowego Centrum Nauki, nr DEC-2012/05/B/HS6/03876. Kierowniczka projektu: Marcjanna Nóżka, zespół: Przemysław Budziło, Adam Dąbrowski, Natalia Martini, Konrad Stępnik.
} 
względnie trwała ocena ludzi, rzeczy, zdarzeń i pojęć, w której uwzględniane są elementy poznawcze (wyobrażenia) i afektywne (wartościowanie - uczucia, które zwykle sprowadzają się do lubienia/nielubienia obiektu postawy) (por. Aronson, Aronson 2009; Katz, Stotland 1959). Poszukując zatem odpowiedzi na pytania: Jakie są wyobrażenia badanych na temat zamieszkiwanej przez nich przestrzeni? Jakie mają wobec niej odczucia?, odwołałam się do koncepcji przestrzeni egzystencjalnej, która ustrukturyzowana jest przez nadane jej znaczenia, intencje i wartości (por. Pallasmaa 2009). Ludzie dysponują względnie stabilnym systemem schematów poznawczych konstytuujących przestrzeń egzystencjalną. Schematy te rozwijane są w interakcji $\mathrm{z}$ otoczeniem, w codziennym doświadczeniu, tak aby móc się w nim orientować i funkcjonować w satysfakcjonujący sposób. Konstruowane są na kilku poziomach: geografii i krajobrazu, miasta, domu i rzeczy, możliwego ruchu (Norberg-Schulz 1971). Inspirując się ustaleniami Norberga-Schulza i wynikami badań pilotażowych, wyróżniłam trzy poziomy analizy przestrzeni egzystencjalnej, a zarazem trzy przestrzenie mobilności, tj. potencjalnego ruchu badanych osób - symbolicznie zobrazowane w układzie koncentrycznym na rysunku nr 1 . Obejmują one podwórko, teren bezpośrednio przylegający do zamieszkiwanego przez osoby badane budynku (poziom mikro); najbliższą okolicę, przestrzeń poza podwórkiem, o zróżnicowanym zasięgu, czasami identyfikowaną jako kwartał ulic, osiedle, innym razem dzielnica (poziom mezo); miasto, obszar, który znajduje się poza zdefiniowaną przez uczestników badań najbliższą okolicą i składa się na szerszy społeczno-geograficzny kontekst (poziom makro). W projekcie za emanację komponentu behawioralnego (zachowania) postaw wobec zamieszkiwanej przestrzeni uznałam zatem mobilność, którą analizowałam w odniesieniu do każdej z wyróżnionych przestrzeni, uwzględniając m.in. preferowany i/lub możliwy w opinii badanych kierunek ruchu, tj. wewnątrz vs. na zewnątrz danej przestrzeni.

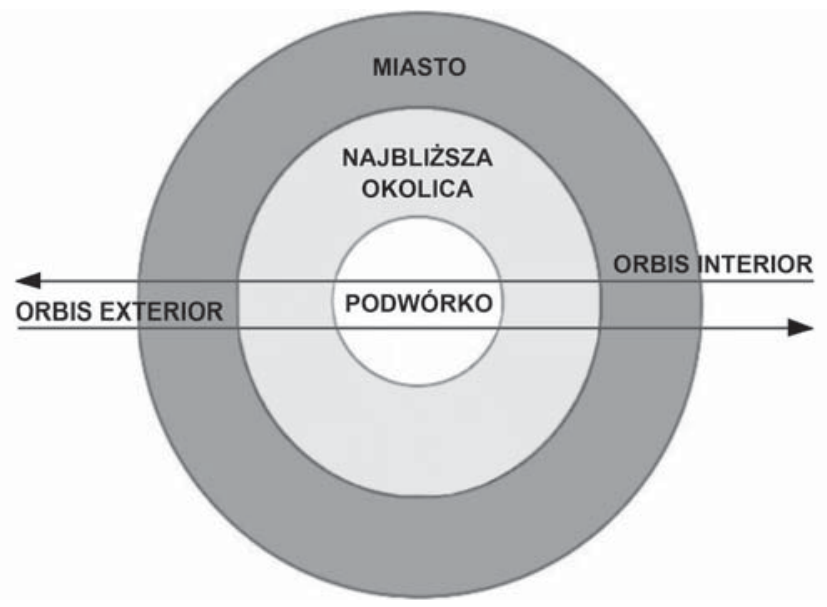

Rysunek 1. Poziomy analizy przestrzeni egzystencjalnej i potencjalnego ruchu Źródło: opracowanie własne. 
Mimo że przedstawione na rycinie (Rysunek 1) przestrzenie zawierają się w sobie, to w ludzkiej wyobraźni i doświadczeniu mogą być od siebie izolowane. Miejsce ma swoją granicę czy też limit, dlatego może być doświadczane jako „wewnętrze”, w przeciwieństwie do otaczającego go "zewnętrza” (Norberg-Schulz 1971). W związku z tym, że schematy wiedzy konstytuujące przestrzeń egzystencjalną rozwijane są $\mathrm{w}$ interakcji $\mathrm{z}$ otoczeniem, to, w zależności od stopnia jego znajomości, akceptacji i podejmowanych aktywności, każda $z$ wyróżnionych przestrzeni potencjalnie może być uznana za teren swój lub obcy. Zmienne może być zatem to, co ludzie uznają za „wnętrze” i zewnętrze”. Obcy świat teoretycznie może być tuż za progiem mieszkania, a swój w innej dzielnicy miasta.

Wykorzystane $\mathrm{w}$ projekcie metody badawcze inspirowane były pracami Kevina Lyncha (1960) oraz Petera Goulda (1973). Pierwszy badał fizyczne struktury przestrzeni, interpretując szkice wyobrażeniowe, drugi analizował przestrzenne preferencje badanych uzyskane drogą wywiadu. Jako uzupełnienie zastosowałam mobilną metodę wizualną (fotospacer), uwzględniając, że ludzie zbierają i aktywizują informacje na temat otoczenia za pośrednictwem zmysłów i bezpośredniego doświadczania przestrzeni. Opracowując metodologię badań, sięgnęłam zatem po zróżnicowane sposoby wydobywania (aktywizowania), uzewnętrzniania i wykorzystywania przez ludzi wiedzy zawartej w mapach mentalnych/wyobrażeniowych. Pierwszy polega na wizualizacji, drugi - referowaniu, trzeci - odwiedzaniu i odczuwaniu określonych przestrzeni.

W i z u a l i z a c j a wiązała się z obrazowaniem wiedzy przestrzennej przez osoby uczestniczące w badaniu, co polegało na wykonaniu rysunku lub szkicu. W tym celu wykorzystano:

- Schematyczny rysunek ogrodzenia - służył identyfikacji przestrzennych wyobrażeń, odczuć i mobilności ludzi na poziomie mikro. Osoba uczestnicząca w badaniu wykonywała rysunek preferowanego typu ogrodzenia wokół umieszczonego na kartce - symbolizującego zamieszkiwany przez nią budynek - schematu domu. Następnie proszona była o wskazanie wysokości ogrodzenia, materiału z jakiego byłoby wykonane, jaka byłaby jego funkcja.

- Mapy szkicowe najbliższej okolicy - służyły identyfikacji przestrzennych wyobrażeń, odczuć i mobilności ludzi na poziomie mezo. Osoba uczestnicząca w badaniu otrzymywała kartkę, na środku której zaznaczony był punkt symbolizujący miejsce realizacji badań. Następnie proszona była o naszkicowanie ulic, budynków i innych obiektów znajdujących się w najbliższej okolicy. Proszona była o narysowanie tego, co pamięta i co zmieści się na kartce, oraz o opisywanie tego, co rysuje. Podczas wykonywania rysunku zadawane były pytania, m.in.: Czy osoba badana lubi daną okolicę? Czy to dobra okolica? Czy jest bezpieczna? Czy czuje się w niej jak u siebie?

- Schematyczny rysunek granic okolicy - służył identyfikacji przestrzennych wyobrażeń, odczuć i mobilności ludzi na poziomie makro. Zadanie polegało na narysowaniu granic najbliższej okolicy na kartce, której brzegi symbolicznie reprezentowały administracyjne granice miasta. Sporządzaniu rysunków 
towarzyszyły pytania: a) po czym osoba badana poznałaby, wracając z podróży, że jest już w zamieszkiwanej przez siebie okolicy [co znajduje się wewnątrz], b) po czym poznałaby, że opuściła zamieszkiwaną przez siebie okolicę [co znajduje się na zewnątrz].

R e f e r o w a n i e obejmowało opisy rysunków i szkiców, odpowiedzi na pytania zawarte w kwestionariuszu wywiadu oraz swobodne wypowiedzi uczestników badań $\mathrm{w}$ trakcie fotospacerów. Kwestionariusz składał się z wystandaryzowanych pytań, które dotyczyły kwestii związanych z identyfikacją, waloryzacją i użytkowaniem danej przestrzeni, np.: Jak uczestnik badania nazwałby zamieszkiwaną okolicę? Jak długo tutaj mieszka? Czy lubi chodzić po okolicy? W ten sposób uzyskano dodatkowe informacje pozwalające określić potencjalną znajomość mapowanej przestrzeni oraz aktywizowano powiązane z nią struktury wiedzy. Ponadto, chcąc ustalić pozytywne i negatywne ustosunkowania osób badanych (por. Katz, Stotland 1959) wobec zamieszkiwanych i (nie)przemierzanych przez nich na co dzień przestrzeni, pytano m.in.: Czy zamieszkiwana okolica jest dobra?, Czy ją lubią?, Czy czują się w niej bezpiecznie? (por. Bem 1970; Fishbein, Ajzen 1975).

Odwiedzanie i odczuwanie wiązało się z realizacją fotospacerów. Wizytowane i fotografowane były miejsca zobrazowane wcześniej przez osoby badane na mapie szkicowej i opisane w trakcie wywiadu. Robienie zdjęć miało zachęcać uczestników badań do ukierunkowania uwagi na elementy przemierzanej przestrzeni, a jej opisy służyły weryfikacji ich opinii dotyczących przestrzennej mobilności. Zebrany materiał uzupełniał oraz ożywiał dane na temat sposobów wyobrażania i waloryzowania zamieszkiwanej okolicy.

\section{WYOBRAŻENIA I WALORYZACJA ENKLAW BIEDY \\ - PRZESTRZENIE WYŁACCZENIA I SPOŁECZNEJ INKLUZJI}

Wypowiadając się na temat najbliższej okolicy, uczestnicy badań rzadko wprost przywoływali ubóstwo jako wyróżniającą ją cechę, zdecydowanie częściej mówili o deficytach społecznej tkanki (np. głośnych, agresywnych zachowaniach, alkoholizmie osób z sąsiedztwa, obojętności mieszkańców na sprawy lokatorskie, sąsiedzkich awanturach), złej jakości przestrzeni (np. niewyremontowanych budynkach, sypiącym się tynku, krzywych chodnikach, niedoborze ławek), brudzie i dewastacji, zaniedbywaniu okolicy i jej lokatorów przez administrację, inwestorów, władze lokalne. Wskazując na gorszy charakter okolicy, niektórzy odwoływali się do opinii ludzi z zewnątrz, eksponując jej negatywny społeczny wizerunek: Slumsy, tak czasami mówią (23.2.S²). Równocześnie część z nich podejmowała polemikę z tego rodzaju

\footnotetext{
${ }^{2}$ Skrót zawiera liczbę porządkową osoby badanej (1-32), numer porządkowy enklawy (1-2), informację, czy uczestnik badania mieszka w danej okolicy od urodzenia ( $\mathrm{S}$ - „swój”), czy wcześniej mieszkał gdzieś indziej $(\mathrm{O}-$ „obcy”).
} 
opiniami, stosując zróżnicowane techniki rekonstrukcji i korekty obrazu zamieszkiwanej przez siebie okolicy. Polegały one m.in. na podkreślaniu wyjątkowości miejsca, przywoływaniu pozytywnych z nim skojarzeń, wybielaniu lub dystansowaniu się od tego, co negatywne. Nie brakowało głosów, że okolica jest zielona, ładna i spokojna, a ludzie przyjaźni. Mimo że tylko pięć osób uznało najbliższą okolicę za bezpieczną, a 16 chciałoby się z niej wyprowadzić, to większość deklarowała, że ją lubi (25 osób), postrzega jako dobrą (21 osób) i czuje się w niej jak u siebie (27 osób). Podobnie tylko pięć osób powiedziało, że nie podoba im się zamieszkiwana okolica, a dwie, że czują się w niej obco.

Odwołując się do wypowiedzi uczestników badań, wyróżnić można trzy typy związków, w jakich pozostają oni z zamieszkiwaną okolicą: przedmiotowe, podmiotowe i emocjonalne. Związki przedmiotowe wiązały się z posiadaniem określonych dóbr i możliwości ich użytkowania (jak mieszkanie czy przyległy do niego ogródek) oraz znajomością okolicy w sensie topograficznym i łatwością nawigowania w tej przestrzeni.

Znam okolicę, mogę wyjaśnić przyjezdnemu co, gdzie jest (31.2.S).

Sam fakt zamieszkiwania okolicy nie był wystarczający, aby osoba badana uznała ją za lubianą lub własną. Przekonanie o jej złej jakości i małej atrakcyjności lokatorów rodziło ambiwalencję:

Lubię tą okolicę, bo dzięki temu mam w ogóle gdzie mieszkać; ale nie lubię jej, bo tu się nie da polubić, hałas, rozboje, brak centralnego ogrzewania... (29.2.O).

Związki podmiotowe zidentyfikowałam natomiast na podstawie deklarowanych przez uczestników badań relacje z innymi ludźmi, bliskości rodziny i znajomych osób. To także bycie rozpoznawalnym i lubianym, co - w opiniach osób badanych - sprzyja poczuciu swojskości, swobody i bezpieczeństwa:

Znam ludzi i wiem, że mi się krzywda nie stanie (13.1.S).

Z uzyskanych wypowiedzi wnioskuję, że życie wśród osób znajomych może dawać poczucie bezpieczeństwa także w sytuacji, gdy okolica i zamieszkujący ją ludzie są postrzegani jako niebezpieczni. Jedna z badanych kobiet, która deklarowała, że nie lubi chodzić po okolicy, ponieważ się boi, dodała:

Tu mam znajomych, rodzinę. Mam bezpieczeństwo. Jakby coś się stało, to każdy za mna stanie, mam opiekę każdego (01.1.S).

Związki emocjonalne $\mathrm{z}$ okolicą konstytuowały miłe wspomnienia i identyfikacja $\mathrm{z}$ miejscem, co zwykle powiązane było z deklarowanym zamieszkaniem danej okolicy od urodzenia. Głównym wątkiem, który pojawiał się w wypowiedziach wieloletnich mieszkańców enklaw, było przyzwyczajenie i swego rodzaju wrośnięcie w daną przestrzeń.

Tu się wychowałem, czuję się normalnie. Nikt mnie nie zaczepia, nie grozi, z sąsiadami żyję dobrze, znam tu każdy zakamarek, każde podwórko (02.1.S). 
Ja jestem urodzony tutaj, mam dużo znajomych, którzy mieszkają po całej dzielnicy. No i zżyłem się $z$ tą dzielnica od dzieciństwa (20.2.S).

Niektórzy uczestnicy badań deklarowali natomiast, że zamieszkiwana okolica nie ma dla nich żadnej wartości w sensie emocjonalnym, ekonomicznym czy społecznym. Dwie osoby nie tylko nie identyfikowały się z nią, ale też miały poczucie wyalienowania i opresji miejsca. W trakcie wywiadu powiedziały, że najchętniej wyprowadziłyby się, ale nie mają dokąd. Odsłania to - w moim przekonaniu - szczególny problem, jakim jest poczucie egzystencjalnej pustki wynikającej z braku przynależności do jakiegokolwiek miejsca. Wśród uczestników badań znalazły się także osoby, które z jednej strony nie czuły się w najbliższej okolicy jak u siebie, $\mathrm{z}$ drugiej zaś deklarowały, że mają swoją przestrzeń gdzieś indziej - zwykle było to dawne miejsce zamieszkania. Wnioskując z ich wypowiedzi, fizyczna i/lub psychiczna dostępność takiego - swojego - miejsca, tj. już samo jego wspomnienie, stanowiło dla nich kapitał, źródło pozytywnych odniesień.

[nie czuję się tu jak u siebie] to nowa okolica, nowe miejsce. U siebie czuję się tam, gdzie się urodziłem, to znane tereny, znani ludzie, mam do nich sentyment $i$ ich pamięć (22.2.O).

Osoby będące stałymi rezydentami enklaw, lecz i te o krótszym stażu lokatorskim, zwracały również uwagę na istnienie nader sztywnej - w moim przekonaniu - więzi, utrudniającej lub uniemożliwiającej mobilność. Mowa tutaj o przywiązaniu, które nie oznacza pozytywnie nacechowanego afektywnego związku z miejscem zamieszkania i jego lokatorami (por. Hernández et al. 2007), ale wynika z postrzegania go jako przestrzeni bezalternatywnej przynależności, tj. konieczności bycia w danym miejscu:

Ludzie tutaj mieszkają, bo muszą. Przyzwyczajenie. Mieszkają tutaj od samego początku, urodzili się i wychowali tutaj (05.1.O).

Na mobilność osób badanych, a w tym poczucie swobody w przemieszczaniu się, miały też wpływ ich subiektywne przekonania o możliwości wyboru miejsca zamieszkania/pobytu:

Mogliśmy się przeprowadzić do męża pod Płock, ale ja zdecydowałam, że zostaniemy tutaj. [...] niektórzy mogliby się tutaj czuć niekomfortowo, natomiast ja czuję się tu bezpiecznie, znajomo. Można powiedzieć, że znam ludzi, znam okolicę (31.2.S).

Odwołując się do opinii uczestników badań, wyobrażenia na temat zamieszkiwanej okolicy i jej waloryzacja warunkowane były szeregiem subiektywizowanych i relatywizowanych okoliczności. To, co czyniło przestrzeń nieprzyjazną dla jednych, przez innych nie było tak postrzegane, np. ze względu na dobrą znajomość okolicy i zamieszkujących ją ludzi, zinternalizowanie określonych wzorów zachowań i standardów życia. W enklawach biedy, to, co swoje i obce, bezpieczne i niebezpieczne, ładne i brzydkie, przenika się. Krzywy chodnik to zarówno wyraz braku zainteresowania władz miejskich okolicą, jak i znacznik tego, co w tym miejscu niepowtarzalne. Jeden z uczestników badań zapytany, czy lubi zamieszkiwaną okolicę, odpowiedział, 
że nie, bo zamieszkują ją menele, ale na pytanie czy czuje się w niej, jak u siebie, odpowiedział, że tak: ten syf, ten brud, ci pijani ludzie wytaczajacy się z pubów [...], myślę, że to ma swój urok. To cały czas widziało się w dzieciństwie (10.1.S). Enklawy biedy doświadczane jako orbis interior nie zawsze więc były postrzegane jako miejsca atrakcyjne. Sam fakt zamieszkiwania enklaw nie musiał oznaczać ich oswojenia, bywało, że swój świat identyfikowany był na zewnątrz, a w miejscu aktualnego zamieszkania rozciągał się nieznany i niebezpieczny świat obcych. W skrajnych sytuacjach enklawa pozostając orbis exterior stanowiła tolerowaną, choć niezmiennie nieakceptowaną i niewartą poznania codzienność.

\section{OBSZARY ZAMIESZKANE I (NIE)PRZEMIERZANE}

- ANALIZA NA POZIOMIE MIKRO, MEZO I MAKRO

Wyobrażenia zamieszkiwanych przestrzeni i ich waloryzacja odzwierciedlone zostały zarówno w wypowiedziach osób biorących udział w badaniu, jak i na wykonanych przez nich rysunkach i mapach szkicowych. Ich analiza pozwoliła także ustalić preferowane obszary mobilności oraz jej kierunki. Identyfikując przestrzenne wyobrażenia, odczucia i mobilność ludzi na poziomie mikro, wykorzystałam zadanie polegające na naszkicowaniu i opisie ogrodzenia domu, który znajdował się na kartce i symbolizował zamieszkiwany przez uczestnika badań budynek. Wysokie, zamknięte i wytrzymałe ogrodzenia (z metalu, betonu, tytanowej siatki) rysowane były przez osoby, które twierdziły, że w okolicy znajdują się potencjalni dewastatorzy i szkodnicy, ludzie wścibscy i nachalni, w jakimś stopniu nieprzewidywalni lub niebezpieczni.

Ogrodzenie powinno być z płyt betonowych. Mogłoby być z siatki, jakby okolica była spokojniejsza (05.1.O).

Beton albo stal, to trudniej zdewastować [...]. Żeby obcy nie wchodzili, alkoholu nie pili na terenie (09.1.O).

Osoby te mówiły o potrzebie większego poczucia prywatności i kontroli, nad tym, co dzieje się na zewnątrz i wewnątrz grodzonej przestrzeni. Ale tylko część z nich uznała, że nie lubi chodzić po okolicy i najchętniej wyprowadziliby się z niej. Kilku uczestników badań podkreślało natomiast, że nie lubią się ogradzać, chcą być widziani i widzieć, co dzieje się na zewnątrz, mieć swobodę przemieszczania się i daliby taką swobodę innym.

Nie chcę zasłaniać się przed ludźmi i światem (17.2.S).

Nie chciałabym się ogradzać, kojarzy mi się to źle, z jakąś izolacją, z zamknięciem. Jeżeli musiałabym się grodzić, to byłby to niski, kolorowy płotek, taki dla ozdoby (26.2.S).

Uwzględniając to, jak uczestnicy badań interpretowali umieszczony na kartce rysunek domu, można lepiej zrozumieć ich sposób postrzegania zamieszkiwanej przestrzeni. Większość z nich uznała, że ogradza całą kamienicę wraz z jej lokatorami. Część z nich otoczenie budynku postrzegało jako wrogie, inni jako przyjazne, czemu 
towarzyszyły stosownie zamknięte lub otwarte, wysokie lub niskie płoty, jednak ludzie zamieszkujący budynek zwykle włączani byli w obszar orbis interior. Natomiast kilka osób, które równocześnie deklarowały, że nie lubią chodzić po okolicy i najchętniej wyprowadziłyby się z niej, narysowany na kartce dom zdefiniowało jako własne mieszkanie. Dla nich orbis exterior zaczynał się już za progiem zamieszkiwanego lokalu.

Przestrzenne wyobrażenia, odczucia i mobilność ludzi na poziomie mezo ustaliłam na podstawie map szkicowych najbliższej okolicy. Uwzględniając umieszczone na rysunkach elementy infrastruktury budowlanej i drogowej oraz sposób ich rozlokowania na kartce, wyróżniłam sześć rodzajów map: [1] sieci dróg z obiektami - szkice zawierały połączone ze sobą drogi i obiekty, przypominały mapy kartograficzne (rys. 2); [2] droga z obiektami - uwzględniały jedną ścieżkę i zlokalizowane w relacji do niej różne obiekty: budynki mieszkalne, urzędy, parki itp. (rys. 3); [3] sieci dróg bez obiektów - na szkicach były umieszczone wyłącznie połączone ze sobą ścieżki (rys.4); [4] mapy domocentryczne - rysowane w układzie promienistym (rys. 5) lub grodzonym (rys. 6). Pierwsze przedstawiały linie (ścieżki) rozchodzące się od domu osoby badanej do różnych miejsc zlokalizowanych wewnątrz okolicy. Na drugich miejsce zamieszkania było otaczane elementami infrastruktury drogowej i budowlanej; [5] obiekty bez dróg - na mapie znajdowały się wyłącznie elementy

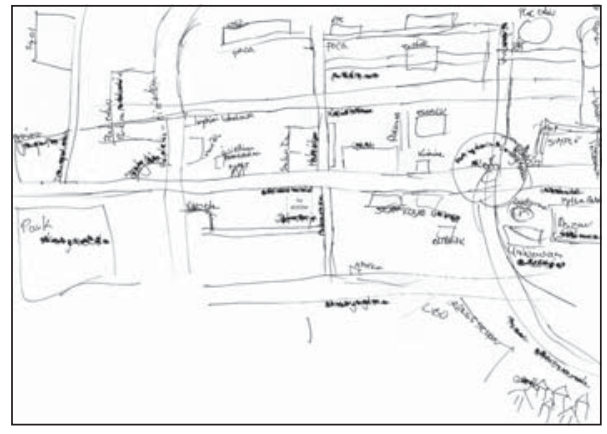

Rysunek 2 (17.2.S)

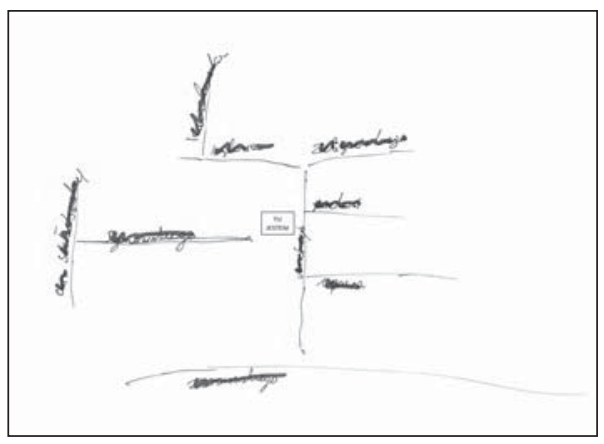

Rysunek 4 (09.1.O)

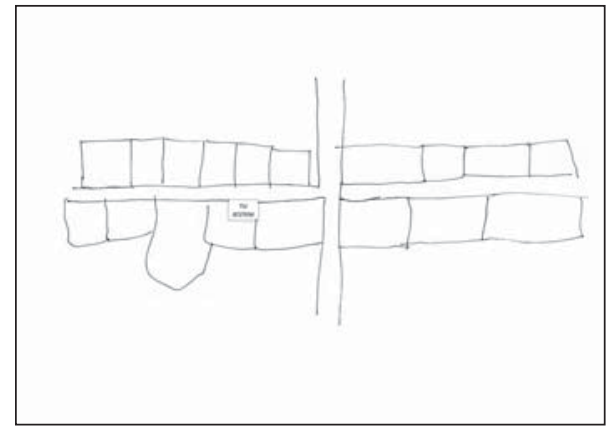

Rysunek 3 (02.1.O)

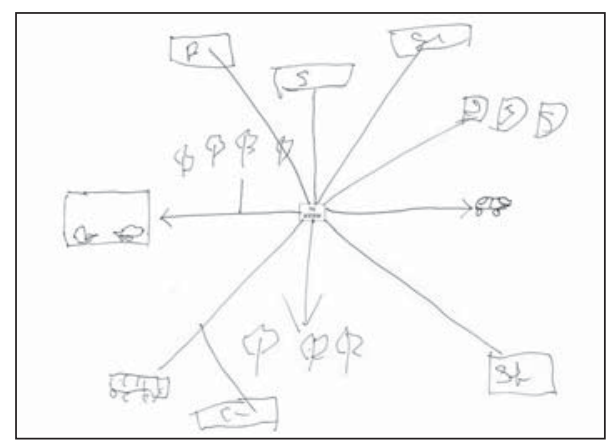

Rysunek 5 (20.2.S) 


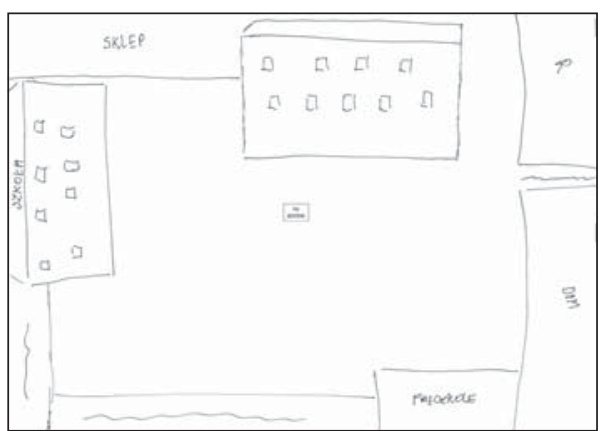

Rysunek 6 (22.2.O)

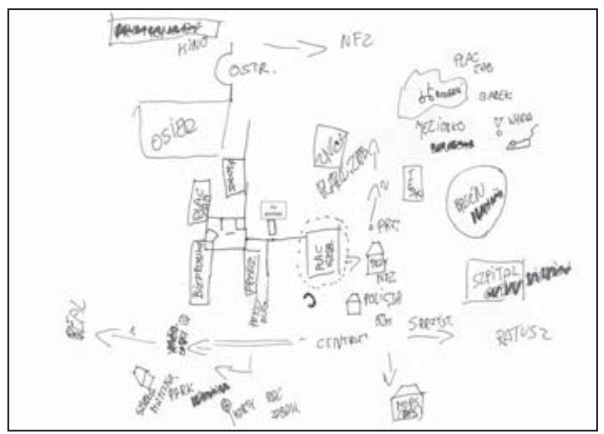

Rysunek 8 (23.2.S)

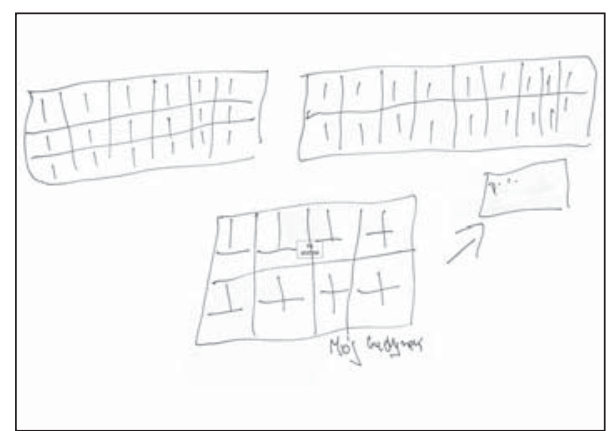

Rysunek 7 (01.1.S)

* W celu zilustrowania map w artykule umieściłam te wykonane przez uczestników badań, natomiast stworzone przeze mnie modele map zostały zaprezentowane i omówione w publikacji: Nóżka 2016.

infrastruktury budowlanej (rys. 7); [6] układy fragmentaryczne - szkice zawierały niepołączone ze sobą obiekty i fragmenty ścieżek (rys. 8) (Nóżka 2016).

Osoby badane, opisując szkic, wskazywały na intencję narysowania lub pominięcia na nim pewnych elementów. Mówiąc o tym, co rysują lub czego nie rysują na mapie i dlaczego, zwracały uwagę na to, co ich zdaniem jest użyteczne vs. nieużyteczne, bezpieczne $v s$. niebezpieczne, uczęszczane $v s$. nieuczęszczane, wyraziste $v s$. obojętne. Na rysunkach uwzględniano te obszary czy obiekty, które na co dzień były przemierzane i użytkowane:

Po tej stronie nic nie ma, dlatego jest zupetnie pusto. Tutaj chodziłabym bez sensu (17.2.S).

A tam dalej to już nie będę rysowat, bo tam nie chodzę. Rysuję to, gdzie mniej więcej przebywam (05.1.O).

Narysowałam to, z czego korzystam, jak jeżdżę i tak dalej... (30.2.O).

Na wyobrażenia najbliższej okolicy składały się nie tylko obiekty materialne, ale także zamieszkujący ją ludzie, podejmowane aktywności, lokalne historie itd. Uczestnicy badań, opisując wykonane przez siebie mapy, czasami waloryzowali własną okolicę jako znaną i oswojoną, a puste przestrzenie stanowiły dla nich zewnętrzne, nieznane lub/i niebezpieczne rejony orbis exterior: Na pótnoc od ulicy X byta strefa 
zakazana, tam było więcej rodzin patologicznych. To była ta granica, gdzie nie jeździłem dalej i nie chodziłem sam (10.1.S). Innym razem niemal pustą przestrzenią była ta aktualnie zamieszkiwana, opisywana jako brzydka, niebezpieczna, obca względem lokowanego na zewnątrz orbis interior:

Tu jest brzydko, ponuro, nie ma terenów zielonych. Oddycha się spalinami. Młodzież pije i szuka zaczepki, nie ma w ogóle szacunku. Tam, gdzie mieszkałem, jest ładnie zalesione, tam się wychowałem, znam każda dziurę (09.1.O).

To, jak obrazowano okolicę na mapach szkicowych, odzwierciedlone zostało w trakcie fotospacerów. Osoby, których mapy szkicowe były ubogie w szczegóły, także wybraną przez siebie trasę fotospaceru opisywały oszczędnie, przechodziły ją w milczeniu, pomimo zachęcania ich do wypowiadania się o tym, co znajduje się w okolicy i co ją wyróżnia:

Ja nie przywiązuję wagi do ulic. Nie patrzę. Ja wiem, gdzie mam iść (28.2.S).

Nie lubię chodzić po okolicy, to nie ma sensu, tu jest patologia (13.1.S).

Niektórzy uczestnicy badań podczas fotospaceru w sposób bardziej ożywiony reagowali na dostrzegane $\mathrm{w}$ przestrzeni miejsca i obiekty. Wspominano podejmowane $\mathrm{w}$ danych miejscach aktywności, przypominano sobie związane z nimi historie. Czasami wskazywano kierunek niewidocznych z trasy niebezpiecznych okolic lub odwiedzanych i lubianych przestrzeni. Mapy szkicowe tych osób zawierały więcej szczegółów, a opisy były bardziej rozbudowane.

[fragment swobodnej wypowiedzi zarejestrowany podczas fotospaceru] [...] chyba śmietnik przenieśli, a nie, jest! Wcześniej stał w środku. Fajniejsze klimaty sa w centrum miasta. Tu jest drugie skrzyżowanie, tam w prawo jest nieciekawa okolica, więcej biedy... Ten budynek zostat wyremontowany 4 lata temu. Ten cały rejon to jest zagłębie callcenter łącznie zatrudniające około tysiąca osób... (10.1.S).

Przestrzenne wyobrażenia, odczucia i mobilność ludzi na poziomie makro ustalone zostały natomiast na podstawie sposobu lokalizowania własnego miejsca zamieszkania w przestrzeni miasta. Uczestnicy badań proszeni o narysowanie granic najbliższej okolicy na kartce, której brzegi symbolicznie reprezentowały administracyjne granice miasta, obrazowali je na cztery dominujące sposoby. Po pierwsze, najczęściej zamieszkiwaną okolicę lokowano centralnie lub peryferyjnie jako wydzielony obszar miasta, z wyraźnie zaznaczonymi granicami. Po drugie, miasto bywało redukowane do własnej okolicy, wówczas brzegi kartki stawały się jej granicami. Po trzecie, zamieszkiwana okolica nie miała zaznaczonych granic, była wkomponowana w miasto za sprawą łączących te przestrzenie ścieżek. Po czwarte, na jednym rysunku zamieszkiwany blok wyobrażony został jako coś niezależnego od miasta, istniejącego obok niego - wyjaśniając, rysunek składał się z dwóch prostokątów, jeden przedstawiał zamieszkiwaną okolicę, drugi symbolizował miasto.

Odnosząc się do wspomnianych sposobów obrazowania czy też umiejscawiania własnej okolicy w przestrzeni miasta, zaznaczę, że część osób badanych całe miasto uznawało za zamieszkiwaną przestrzeń. Na pytanie, po czym poznałyby, że są 
poza swoim miejscem zamieszkania, wskazywały na drogowskazy i/lub tablice informacyjne sygnalizujące koniec miasta, polne drogi, zmianę miejskiej infrastruktury w podmiejską/wiejską. Dla innych zaś wskaźnikiem bycia poza miejscem zamieszkania były drogi, mosty wyjazdowe bądź ścieżki wyprowadzające z najbliższej okolicy lub przystanki autobusowe znajdujące się poza jej granicami. Generalizując, nieswoje miejsce zdaniem uczestników badań wyróżnia: (a) inna zabudowa; (b) inny krajobraz; (c) inne doświadczenia sensoryczne: dźwiękowe, zapachowe, kinestetyczne; (d) inni ludzie: ich wygląd, język, zachowanie się; (e) inne natężenie ruchu: ludzkiego, samochodowego; (f) inna infrastruktura drogowa i/lub komunikacyjna. Przestrzeń nie tylko zmienia się, ale też staje się nieznana:

Wszystko inne, inne zapachy inne otoczenie, domy, to jest coś, co jest za mną, coś nowego, inni ludzie, budynki inaczej ustawione (22.2.O).

Uczestnicy badań wskazywali również na poczucie wyobcowania, wewnętrzne odczucia sygnalizujące, że opuszczają znane sobie miejsce: Świadomość mi mówi, że to już nie jest moje miasto (29.2.S). Na wewnętrzne odczucia zwracali uwagę także wtedy, gdy mówili, po czym poznaliby, że wracają do swojego miejsca zamieszkania. O ile jednak doświadczenie bycia na zewnątrz - częściej w przypadku stałych rezydentów - związane było z uczuciem wyobcowania, to powrotom zwykle towarzyszyły odczucia przyjemne, związane m.in. z rozpoznawaniem innych i byciem rozpoznawanym, np.:

Bardzo dobrze bym się tutaj poczuła, tutaj jest mój dom. Ludzie zaczęliby mi mówić dzień dobry, cześć, i po tym bym poczuła, że jestem u siebie (11.1.S).

Poza tym wskaźnikiem bycia u siebie w opiniach osób badanych były wyróżniające się obiekty oraz znajomy układ ulic i budynków.

\section{POSTAWY MIESZKAŃCÓW ENKLAW BIEDY WOBEC ZAMIESZKIWANEJ PRZESTRZENI - PROPOZYCJA KLASYFIKACJI}

Zbiorcza analiza zgromadzonego materiału pozwoliła ustalić zmienne różnicujące postawy uczestników badań wobec zamieszkiwanej przez nich przestrzeni. Po pierwsze, odwołując się do ich opinii i wyobrażeń, zidentyfikowałam, czy i na którym z wyróżnionych poziomów analizy przestrzeni egzystencjalnej identyfikują oni orbis interior, a gdzie i czy w ogóle $\mathrm{w}$ ramach wyróżnionych przestrzeni miasta lokują orbis exterior. Po drugie, ustaliłam powiązane z czynnikiem poznawczo-afektywnym wskaźniki ich mobilności: orientację przestrzenną (implozyjną i eksplozyjną) oraz zachowania przestrzenne (eksploracyjne, eskapistyczne, inercyjne).

Uczestnicy badań, tworząc oraz opisując rysunki i mapy szkicowe, a także w trakcie fotospaceru, w mniejszym lub większym stopniu koncentrowali się na prezentowaniu tego, co wewnątrz i na zewnątrz zamieszkiwanej okolicy - stanowiło to podstawę ustalenia ich orientacji przestrzennej. Implozyjna orientacja przestrzenna 
oznaczała orientację do wewnątrz i opisywanie tego, co „tutaj”. Tak zorientowane osoby badane zwykle deklarowały, że nie chcą lub nie mogą przebywać poza zamieszkiwaną enklawą. Dla jednych wyobrażane granice między wyróżnionymi obszarami miasta (podwórkiem, najbliższa okolicą i miastem) uczytelniały miejską przestrzeń, oddzielały to, co znane i oswojone, od tego, co obce i niepewne. Dla innych, granice oznaczały zamknięcie w niepożądanych społecznych relacjach, nieakceptowanych i niebezpiecznych przestrzeniach. Eksplozyjność oznaczała natomiast orientację na zewnątrz, koncentrowanie się albo na tym, co „tutaj” i „tam”, albo wyłącznie na tym, co „tam”, tj. poza zamieszkiwaną okolicą. Otwarcie na to, co znajduje się na zewnątrz zamieszkiwanej enklawy było różnie uzasadniane. Część osób uczestniczących w badaniach deklarowała zaciekawienie tym, co znajduje się na zewnątrz, i lokowało tam codzienne aktywności (np. odwiedzali znajomych i rodzinę, robili zakupy). Osoby te opisywały całe miasto w kategoriach orbis interior. Eksplozyjność wyróżniała także uczestników, dla których zamieszkiwana okolica była orbis exterior, a swoje aktywności lokalizowały w dawnym miejscu zamieszkania, gdzie na co dzień spędzały czas, $w$ otoczeniu znanych oraz lubianych przez siebie przestrzeni i osób. Eksplozyjne bywały także osoby, które nie potrafiły wskazać żadnej przestrzeni, którą mogłabym określić orbis interior. Nigdzie na terenie miasta nie czuły się jak u siebie, całe miasto postrzegały jako orbis exterior. Wobec zamieszkiwanych i przemierzanych przestrzeni pozostawały zwykle obojętne, na zasadzie: mieszkam tutaj i chodzę po okolicy, bo muszę.

Osoby uczestniczące w badaniach wykazywały zatem zróżnicowane zainteresowanie tym, co je otaczało, tym co jest dostępne i dzieje się w ich miejscu zamieszkania oraz jego otoczeniu. Na tej podstawie wyróżniono zachowania przestrzenne: eksploracyjne, eskapistyczne i inercyjne. Pierwsze oznaczały lepszą znajomość okolicy i skłonność do jej penetrowania, drugie jej unikanie i niechętne przemierzanie, trzecie obojętny stosunek do zamieszkiwanej okolicy. Uwzględniając te zmienne, wyróżniłam sześć modeli postaw wobec zamieszkiwanej przestrzeni (tabela 1).

Tabela 1. Modele postaw wobec zamieszkiwanej przestrzeni

\begin{tabular}{|l|l|l|l|}
\hline & \multicolumn{1}{|c|}{ Eksploracja } & \multicolumn{1}{c|}{ Eskapizm } & \multicolumn{1}{c|}{ Inercja } \\
\hline Eksplozyjność & $\begin{array}{l}\text { Postawa otwarta } \\
\text { eksploracyjna }\end{array}$ & $\begin{array}{l}\text { Postawa otwarta } \\
\text { eskapistyczna }\end{array}$ & $\begin{array}{l}\text { Postawa otwarta } \\
\text { inercyjna }\end{array}$ \\
\hline Implozyjność & $\begin{array}{l}\text { Postawa zamknięta } \\
\text { eksploracyjna }\end{array}$ & $\begin{array}{l}\text { Postawa zamknięta } \\
\text { eskapistyczna }\end{array}$ & $\begin{array}{l}\text { Postawa zamknięta } \\
\text { inercyjna }\end{array}$ \\
\hline
\end{tabular}

Źródło: opracowanie własne

Jak zaznaczam, jest to ujęcie modelowe - są to konstrukty poznawcze, pozwalające z jednej strony na wskazanie złożoności badanego zjawiska, a z drugiej na uporządkowanie zgromadzonej wiedzy. Poniżej omawiam natomiast bardziej szczegółowe wskaźniki, które przyczyniły się do ukonstytuowania takiej, a nie innej propozycji klasyfikacji postaw osób badanych wobec zamieszkiwanej przez nich przestrzeni. 
Najczęściej identyfikowaną przeze mnie postawą była p o st a w a $\mathrm{za} \mathrm{m} \mathrm{kn}$ i ę t a e k s p l o r a c y j n a. To postawa, którą uznałam za typową dla badanych osób, które oswoiły zamieszkiwaną przez siebie przestrzeń, nie chciałyby się z niej wyprowadzić, akceptują swoje sąsiedztwo i najbliższą okolicę - to ich orbis interior. To zwykle stali rezydenci enklawy. Lubią chodzić po okolicy, czują się w niej jak u siebie, natomiast rzadko ją opuszczają lub w ogóle tego nie robią. Poza nią jest orbis exterior - przestrzeń, gdzie nie czują się komfortowo: [poznaję, że jestem poza swoją okolicą] Po ludziach, po atmosferze, jak się nie zna nikogo, to ludzie ida i się patrzq (04.1.S). Badani ci zwykle nie potrafili określić tego, co znajduje się na granicy ich okolicy: Jeżeli coś, to wszystko jest w środku. Nikt szczególnej uwagi nie zwraca na obrzeża (19.2.S). Swoją okolicę natomiast rozpoznawali, odwołując się do przyjemnych wewnętrznych odczuć lub na podstawie znajdujących się na jej terenie obiektów (szyldy sklepów, place zabaw itp.). Mapy szkicowe tych osób zawierają wiele detali, nazwy ulic i obiektów, to zwykle mapy $\mathrm{w}$ rodzaju sieci dróg $\mathrm{z}$ obiektami lub mapy domocentryczne w układzie promienistym. Ogrodzenia wokół domu - zdefiniowanego jako zamieszkiwana kamienica - były zwykle otwarte, stosunkowo niskie (do półtora metra), z transparentnych materiałów (siatka, rośliny, drewno), pełniły funkcje ozdobne lub regulacyjne: żeby nikt obcy nie wchodzit.

Drugi z wyróżnionych modeli to postawa otwarta eksploracyjna, wyróżniała uczestników badań zorientowanych zarówno na wnętrze, jak i zewnętrze zamieszkiwanej okolicy. Deklarowali oni, że lubią chodzić po okolicy, ale też czują się swobodnie poza nią - w enklawie mieszkają, lecz ich życie toczy się w różnych przestrzeniach miasta. I własne podwórko, okolicę, i miasto opisywali w kategoriach orbis interior. Mówiąc o granicach okolicy, zwykle mieli na myśli granice miasta, wskazywali na drogowskazy i/lub znaki z przekreśloną nazwą miejscowości, zmianę miejskiej infrastruktury w podmiejską/wiejską. Mapy szkicowe tych osób - powiązane $\mathrm{z}$ wyróżnionym modelem postawy - to mapy typu quasi-kartograficznego, $\mathrm{z}$ rozbudowaną infrastrukturą drogową i budowlaną, ich wykonaniu towarzyszył bogaty opis tego, co znajduje się w okolicy i poza nią. W trakcie fotospacerów chętnie wypowiadali się na temat przemierzanej przestrzeni, wskazywali kierunki miejsc, w których bywają, i opisywali podejmowane tam aktywności. Zgodnie wskazywali na niechęć do odgradzania się, wykonane ogrodzenia były otwarte i tylko symbolicznie wydzielały grodzoną przestrzeń.

Postawa otwarta eskapistyczna została zidentyfikowana na podstawie opinii i szkiców jednego uczestnika badań, który nie akceptował miejsca aktualnego zamieszkania. Eksmitowano go z poprzedniego mieszkania, które mieściło się na terenie innej enklawy biedy, zlokalizowanej na obszarze tego samego miasta. Tam znów chciałby zamieszkać, w jego orbis interior: Tu jest brzydko, ponuro [...]. Tam gdzie mieszkałem jest ładnie zalesione, tam się wychowałem, znam każda dziure (09.1.O). Eskapizm w tym przypadku oznaczał rzeczywiste spędzanie czasu i lokowanie swoich aktywności na zewnątrz zamieszkiwanej okolicy. Nie lubił tego, co znajdowało się wewnątrz, było to dla niego wrogie i nieznane. Osoba ta podkreślała, że nie lubi chodzić po najbliższej okolicy, a jak do niej wraca, to ma gorsze 
samopoczucie. Badany mężczyzna uznał, że na granicy zamieszkiwanej okolicy nie ma niczego charakterystycznego, potrafił jednak określić obiekty, po których poznaje, że ją opuszcza. Jego mapa szkicowa składała się z wyprowadzających z okolicy ścieżek, a narysowany przez niego żelbetonowy płot - co sam zaznaczył - miał go odgrodzić od obcego sąsiedztwa i niebezpiecznej okolicy: Cały czas muszę się oglądać za siebie, nie mam tutaj żadnego bezpieczeństwa (09.1.O).

Czwarta postawa, zamknięta eskapistyczna, została zidentyfikowana na podstawie danych zgromadzonych wśród kilku stałych rezydentów enklawy, którzy dzielili jej przestrzeń między „ja i moje najbliższe sąsiedztwo” oraz „oni, pozostali mieszkańcy enklawy”. Osoby te zwykle na temat okolicy wypowiadały się w sposób ambiwalentny, np. wskazując na agresywną młodzież na zewnątrz i dobrych sąsiadów, którzy pilnują porządku i są pomocni. Wszyscy badani z tej grupy deklarowali, że w zamieszkiwanej okolicy czują się jak u siebie. Ale wyłącznie osoby $\mathrm{z}$ najbliższego otoczenia - $\mathrm{z}$ wąsko rozumianej sąsiedzkiej enklawy - były akceptowane i to one, jako wspólnota, stanowiły bezpieczny azyl w nieprzyjaznym, chociaż znanym otoczeniu. Orbis interior stanowiło przede wszystkim własne podwórko. Eskapizm w tym przypadku nie oznaczał rzeczywistego spędzania czasu na zewnątrz, wiązał się z unikaniem chodzenia po okolicy i poza nią, a także na odcinaniu się od tego, co w okolicy nieakceptowane - m.in. podkreślano swój brak zgody na dewastowanie przestrzeni i zachowania agresywne oraz obcość ludzi, którzy tak postępują. Rysowane przez tych uczestników badań ogrodzenia wokół domów zawsze były zamknięte i pełniły funkcję ochronną. Ich mapy szkicowe - chociaż zróżnicowane - wskazywały na gorszą znajomość okolicy, nie potrafili też wskazać, co znajduje się poza nią. Najbliższą okolicę rozpoznawali, identyfikując jej negatywne znaczniki (np. smród, brud, korki) lub na podstawie czegoś, co znajduje się w ich bezpośrednim sąsiedztwie (np. ławka na podwórku).

Piąta to postawa otwarta in e rcyjna. Wyróżniała osoby, które miały poczucie przymusu mieszkania $\mathrm{w}$ obcym i negatywnie postrzeganym przez siebie otoczeniu, do którego zaliczały podwórko, najbliższą okolicę i miasto. Postrzegana niemożność opuszczenia tych przestrzeni - stanowiących orbis exterior - warunkowana była dwoma co najmniej okolicznościami. Z jednej strony wynikała $\mathrm{z}$ braku środków finansowych, $\mathrm{z}$ drugiej z braku potencjalnego miejsca, które ci ludzie chcieliby zasiedlić i uznawaliby za własne. Miejsce, gdzie kiedyś mieszkali, przestało być ich terytorium, a nowe miejsce - jak zgodnie zaznaczali - jeszcze się nim nie stało. Zamieszkiwana enklawa to dla nich obcy świat, użytkowany z konieczności: tu przydzielono im mieszkanie i tutaj musza mieszkać. Manifestowało się to obojętnym stosunkiem do okolicy i jej mieszkańców. Hegemonia obcości w tym przypadku wpłynęła na przestrzenną mobilność; czując się wszędzie obco, nie doświadczali blokujących swobodne przemieszczanie się granic między tym co „tutaj” i „tam”. Granice okolicy identyfikowali na rogatkach miasta, natomiast na oszczędnych w szczegóły mapach szkicowych okolicy umieszczali głównie użytkowane na co dzień obiekty (sklep, szkoła dzieci itd.). Od obcego sąsiedztwa przedstawiciele tej grupy badanych najchętniej odgrodziliby się wysokim, zamkniętym lub półotwartym płotem. 
Ostatnia z wyróżnionych postaw, postawa zamknięta in ercyjna, wyróżniała osoby, które orbis interior lokują na zewnątrz zamieszkiwanej okolicy i postrzegają go jako przestrzeń niedostępną - m.in. ze względu na dużą odległość, zerwane więzi rodzinne, nierozwiązane konflikty. Fakt zamieszkiwania w nieakceptowanej okolicy traktowali jako życiową konieczność. Wszystkie te osoby deklarowały, że nie lubią chodzić po okolicy, ponieważ boją się, czują się obco, nie lubią mieszkających tu ludzi. Deklarowali jej małą znajomość i niechęć do eksploracji - towarzyszyło temu poczucie zagrożenia na zewnątrz oraz przekonanie o fizycznej niedostępności dawnych, preferowanych i postrzeganych jako własne przestrzeni. Na mapach szkicowych nie umieszczali wyprowadzających z okolicy ścieżek - były to głównie mapy typu „obiekty bez dróg” oraz „układy domocentryczne grodzone”. Na rysunkach ich mieszkania otaczały m.in. betonowe płyty i stalowe płoty: jak już muszętu mieszkać, to odrobina prywatności się należy (29.2.O).

\section{PODSUMOWANIE}

„Sposób pojmowania i nazywania przestrzeni oraz orientowania się w niej jest jednym z podstawowych przejawów kultury w każdej społeczności” (Feglova 2001, s. 15) - to ludzie przypisują i wartościują jej określone cechy. Z tych m.in. powodów enklawy biedy to przedmiot badań otwarty na eksplorację dla antropologów i socjologów przestrzeni. Enklawy biedy to przestrzenie niejednoznaczne, są społecznie napiętnowane, a zarazem stanowią środowisko życia konkretnych ludzi, przez których są współdzielone i współtworzone. To obszary w społecznej ocenie zdezorganizowane i zdegradowane, na których kumulują się różnego rodzaju problemy. To jednocześnie przestrzenie domowe w pełnym tego słowa znaczeniu: lubiane, bezpieczne, będące źródłem satysfakcji i identyfikacji dla części ich mieszkańców. Ta sama przestrzeń w przekonaniach i odczuciach jednych ludzi może być zatem swojska i bezpieczna, chętnie zamieszkiwana lub odwiedzana, dla innych natomiast będzie obca, wroga, a przez to zwykle unikana, niechętnie przemierzana i eksplorowana. Ze zgromadzonych danych wynika równocześnie, że bycie stałym rezydentem danej okolicy nie stanowi warunku swobody przemieszczania się na jej obszarze, co powiązane jest z zamieszkiwaniem i oswajaniem okolicy stygmatyzującej i stygmatyzowanej, gdzie orbis interior jest przestrzeń negatywnie waloryzowana. Z kolei brak jakichkolwiek przestrzennych identyfikacji, które mogłyby ukierunkować mobilność, okazał się nie stanowić czynnika „blokującego" ruch, w pewnych okolicznościach wręcz go wyzwalał, co znalazło odzwierciedlenie w postawie otwartej inercyjnej.

Zebrany materiał - ze względu na lokalny charakter badań i małą próbę - nie pozwala na stwierdzenie powszechności zidentyfikowanych zmiennych cechujących wyróżnione modele postaw wobec zamieszkiwanej przestrzeni, zwraca natomiast uwagę na wewnątrzkategorialne zróżnicowanie mieszkańców enklaw biedy oraz zachęca do refleksji nad dynamiką życia ludzi w tych przestrzeniach, odsłaniając odmienne sposoby ich doświadczania, opisywania i waloryzowania. 


\section{LITERATURA}

A n n a n A. K of i 2003, Foreword, [w:] The Challenge of Slums - Global Report on Human Settlements 2003, United Nations Human Settlements Programme, Earthscan Publications Ltd., London -Sterling, VA.

A ronson Elli ot, Joshua A r on s on 2009, Człowiek istota społeczna, tłum. Józef Radzicki, Wydawnictwo Naukowe PWN, Warszawa.

B e m J. D a r yl 1970, Beliefs, Attitudes and Human Affairs, Brooks/Cole, California.

B e n n e t $t$ N a t a s h a 2018, The Bottom Two Billion: the Global Expansion of Urban Slums and Secondclass Citizenship, [w:] A. Brysk, M. Stohl (red.), Contracting Human Rights: Crisis, Accountability, and Opportunity, Edvard Elgar Publishing, Santa Barbara, s. 54-70.

Bird Julia, Montebruno Piero, Regan Tanner 2017, Life in a Slum: Understanding Living Conditions in Nairobi's Slums Across Time and Space, Oxford Review of Economic Policy, vol. 33, nr 3, s. 496-520.

B urges s W. Ernest 1925, The Growth of the City. An Introduction to a Research Project, [w:] R.E. Park, E.W. Burgess, R.D. McKenzie (red.), The City, University of Chicago Press, Chicago, s. $47-62$.

Cass Noel, Shove Elizabeth, Urry John 2005, Social Exclusion, Mobility and Access, The Sociological Review, vol. 53, nr 3, s. 539-555.

Church Andrew, Frost Martin E., Sullivan Kevin 2000, Transport and Social Exclusion in London, Transport Policy, vol. 7, nr 3, s. 195-205.

C zekaj Krzys zt of 1999, Mapy problemów społecznych jako narzędzie badawcze ekologii humanistycznej. Aspekty teoretyczne i empiryczne, [w:] M. Malikowski, S. Solecki (red.), Socjologia miasta. Wybór tekstów, Wydawnictwo Wyższej Szkoły Pedagogicznej, Rzeszów, s. 429-439.

D at $t$ a Ay on a 2016, The Intimate City: Violence, Gender and Ordinary Life in Delhi slums, Urban Geography, vol. 37, nr 3, s. 323-342.

D a vis Mike 2006, Planet of Slums, Verso, London-New York.

Dupont Véronique, Jordhus-Lier David, Sutherland Catherine, Brathen E in a r (red.) 2016, The Politics of Slums in the Global South: Urban Informality in Brazil, India, South Africa and Peru, Routledge, Oxon.

Ernst Kacey C., Phillips Beth S., Duncan Burris „Duke” 2013, Slums Are Not Places for Children to Live, Vulnerabilities, Health Outcomes, and Possible Interventions Advances in Pediatrics, vol. 60, nr 1, s. 53-87.

Feglova Viera 2001, Pojmowanie przestrzeni lokalnej w aspekcie antropologicznym. Wyniki badań przeprowadzonych w kilku wsiach środkowej Słowacji, [w:] I. Bukowska-Floreńska (red.), Studia etnologiczne i antropologiczne, t. 5: Miejsca znaczące $i$ wartości symboliczne, Wydawnictwo Uniwersytetu Śląskiego, Katowice.

F is h be in A. Mart in, A j ze n I c e k 1975, Belief, Attitude, Intention and Behavior: An Introduction to Theory and Research, Addison Publishing Company, Reading.

Frenzel Fabian, Koens Ko, Steinbrink Malte, Rogerson Christian M. 2015, Slum Tourism: State of the Art, Tourism Review International, nr 18, s. 237-252.

G o uld Peter 1973, On Mental maps, [w:] R.M. Downs, D. Stea (red.), Image and Environment. Cognitive Mapping and Spatial Behavior, Aldine Publishing Company, Chicago, s. 182-220.

Grob A l ex a n d e r 1995, A Structural Model of Environmental Attitudes and Behavior, Journal of Environmental Psychology, vol. 15, s. 209-220.

Grotowska-Leder Jolanta 2006, Gettyzacja wielkomiejskiej przestrzeni jako współczesne zagrożenie społeczne, [w:] J. Królikowska (red.), Problemy społeczne w grze politycznej. Wspótczesne zagrożenia społeczne - diagnoza i przeciwdziałanie, Wydawnictwo Uniwersytetu Warszawskiego, Warszawa, s. 310-320.

Heberlein A. Thom as 2012, Navigating Environmental Attitudes, Oxford University Press, Oxford. 
Hernández Bernardo, Hidalgo Carmen, Salazar-Laplace Esther, Hess S t e p h a n y 2007, Place Attachment and Place Identity in Natives and Non-Natives, Journal of Environmental Psychology, vol. 27, nr 4, s. 310-319.

Jirón Paola, Lange Carlos, Bertrand Maria 2010, Exclusion and Spatial Inequality: An Analysis from a Daily Mobility Perspective, Revista INVI, vol. 25 (68), https://revistas.uchile. cl/index.php/INVI/article/view/8349/8117, dostęp 14.06.2020.

Jargowsky A. Paul, Steiner Rudolf 1997, Poverty and Place: Ghettos, Barrios, and the American City, Russell Sage Foundation, New York.

Jo nes Nikki 2010, Between Good and Ghetto: African American Girls and Inner-City Violence, Rutgers University Press, New Brunswick, New Jersey, London.

Jorgensen S. Bradley, Stedman Rich ard C. 2001, Sense of Place as an Attitude: Lakeshore Owners Attitudes Toward Their Properties, Journal of Environmental Psychology, vol. 21, s. $233-248$.

Karan Pradyum na P., B la den Wilford A., Singh G. 1980, Slum Dwellers' and Squatters' Images of the City, Environment and Behavior, vol. 12, nr 1, s. 81-100.

Kat z D a ni el, St ot land E z r a 1959, A Preliminary Statement to a Theory of Attitude Structure and Change, [w:] S. Koch (red.), Psychology: A Study of a Science, McGraw-Hill Book Company, New York, s. 423-475.

Kenyon Susan 2006, Reshaping Patterns of Mobility and Ex-clusion? The Impact of Virtual Mobility Upon Accessibility, Mobility and Social Exclusion, [w:] M. Sheller, J. Urry (red.), Mobile Technologies of the City. Networked Cities, Routledge, London, s. 102-120.

Lupton Ruth, Power A n ne 2002, Social Exclusion and Neighbourhoods, [w:] J.R. Hills, J. Le Grand, D. Piachaud (red.), Understanding Social Exclusion, Oxford University Press, Oxford, s. $118-140$.

Ly n ch Kevin 1960, The Image of the City, MIT Press, Cambridge.

Łotman Jurij, Us pie nski B or is 1975, O semiotycznym mechanizmie kultury, [w:] E. Janus, M.R. Mayenowa (red.), Semiotyka kultury, Państwowy Instytut Wydawniczy, Warszawa, s. 177-201.

Madan i p o r A li 2003, Social Exclusion and Space, [w:] R.T. Le Gates, F. Stout (red.), The City Reader, Routledge, London, s. 181-188.

Nę cki Z bi g n i e w 2004, Formowanie się postaw wobec otoczenia - od niewiedzy do nazwy, [w:] Ekologia społeczna - psychologiczne i środowiskowe uwarunkowania postaw, Stowarzyszenie Ekopsychologia, Kraków, s. 111-117.

Norberg-Schulz Christian 1971, Existence, Space and Architecture, Praeger, New York.

Nóżka Marcjan n a 2016, Społeczne zamykanie [się] przestrzeni. O wykluczeniu, waloryzacji miejsca zamieszkania i jego mentalnej reprezentacji, Wydawnictwo Naukowe Scholar, Warszawa.

O o i Ling Giok, Ka i Phu a Hong 2007, Urbanization and Slum Formation, Journal of Urban Health, vol. 84, nr 1, s. 27-34.

Pall a s ma a Juh a n i 2009, Mental and Existential Ecology, Sustainable School Buildings. From Concept to Reality, Ljubljana.

P a w la k M a re k 2015, Recognizing the National Identity: Cultural Intimacy and the Polish Migration to Norway, Prace Etnograficzne, nr 3 (43), s. 241-258.

Potoczna Małgorzata, Warzywoda-Kruszyńska Wielisława 2009, Kobiety $z$ łódzkich enklaw biedy. Bieda w cyklu życia i międzypokoleniowym przekazie, Wydawnictwo Uniwersytetu Łódzkiego, Łódź.

Powell Martin, Boyne George, Ashworth Rachel 2001, Towards a Geography of People Poverty and Place Poverty, Policy \& Politics, vol. 29, nr 3, s. 243-258.

R o gowski Łukas z 2018, Mobilność jako potencjalność: sposoby rozumienia mobilności z perspektywy nowych technologii i paradygmatu mobilności, Ruch Prawniczy, Ekonomiczny i Socjologiczny, R. 80, z. 2, s. 273-286.

S a n d h u R. Sing h 1987, Not All Slums are Alike. A Comparison of Squatter Housing in Delhi and Amritsar, Environment and Behavior, vol. 19, nr 3, s. 398-406. 
Shelle r Mi m i 2017, From Spatial Turn to Mobilities Turn, Current Sociology, vol. 65, nr 4, s. 1-17.

Siddiqui N. Roomana, Pandey Janak 2003, Coping with Environmental Stressors by Urban Slum Dwellers, Environment and Behavior, vol. 35, nr 5, s. 589-604.

S m a 11 L. Mar i o 2015, De-Exoticizing Ghetto Poverty: On the Ethics of Representation in Urban Ethnography, City and Community, vol. 14, nr 4, s. 352-358.

S m it h M. B r e w st e r 1947, The Personal Setting of Public Opinions: A Study of Attitudes Toward Russia, Public Opinion Quarterly, vol. 11, s. 507-523.

Stanley John, Hensher David A., Stanley Janet, Currie Graham, Greene William H., Vella-Brodrick Dianne 2011, Social Exclusion and the Value of Mobility, Journal of Transport Economics and Policy, vol. 45, nr 2, s. 197-222.

Steele E. Jessica, Sundsøy Roe P., Pezzulo Carla, Alegana Victor A., Bird Thomas J., Blumenstock Joshua, Bjelland Johannes, Engø-Monsen Kenth, de Montjoye Yves-Alexandre, Iqbal Asif M., Khandakar Hadiuzzaman N., Lu Xin, Wetter Erik, Tatem Andrew J., Bengtsson L in u s 2017, Mapping Poverty Using Mobile Phone and Satellite Data, Journal of the Royal Society Interface, vol. 14, nr 127, s. 1-10.

St o m m a L u d wik 2000, Antropologia kultury wsi polskiej XIX wieku, Tower Press, Gdańsk.

Tesser Abraham, Dabid Shaffer R. 1990, Attitudes and Attitude Change, Annual Review of Psychology, vol. 41, s. 479-523.

The Challenge of Slums - Global Report on Human Settlements 2003, United Nations Human Settlements Programme, Earthscan Publications Ltd., London-Sterling, VA.

To m a s ze w sk i Ta d e u s z 1984, Ślady i wzorce, Wydawnictwa Szkolne i Pedagogiczne, Warszawa.

Uret a S e b a st i a n 2008, To Move or Not to Move? Social Exclusion, Accessibility and Daily Mobility among the Low-income Population in Santiago, Chile, Mobilities, vol. 3, nr 2, s. 269-289.

Urry John 2007, Mobilities, Polity, Cambridge.

Va ugh a n L a u r a 2008, Mapping the East End 'Labyrinth', [w:] A. Werner (red.), Jack the Ripper and the East End Labyrinth, Chatto \& Windus, London, s. 218-237.

Walks R. Alan, B ourne Larry S. 2006, Ghettos in Canada's Cities? Racial Segregation, Ethnic Enclaves and Poverty Concentration in Canadian Urban Areas, The Canadian Geographer/Le G'eographe Canadien, vol. 50, nr 3, s. 273-297.

Warzywoda-Kruszyńska Wielisława, Jankowski Bogdan 2013, Ciagłość izmiana w łódzkich enklawach biedy, Wydawnictwo Uniwersytetu Łódzkiego, Łódź.

Warzywoda-Kruszyńska Wi l lisława (red.) 1998, Żyć i pracować w enklawach biedy, Instytut Socjologii Uniwersytetu Łódzkiego, Łódź.

Whitehead L. Tony 2000, The Formation of the U.S. Racialized Urban Ghetto, University of Maryland, College Park, Maryland.

Yuting Liu, Wu Fulong 2006, Urban Poverty Neighbourhoods: Typology and Spatial Concentration under China's Market Transition, a Case Study of Nanjing, Geoforum, Vol. 37, nr 4, s. 610-626.

Zdulski Mirosław 2011, Rodzina romska a zdrowie dzieci, Wychowanie w Rodzinie, nr 1, s. 181-204. 
MARCJANNA NÓŻKA

\author{
SPATIAL ATTITUDES AND MOBILITY OF THE INHABITANTS \\ OF URBAN ENCLAVES OF POVERTY IN POLAND
}

Keywords: city, enclaves of poverty, attitudes, space, mobility, sketch maps, Poland

The article focus on various spatial attitudes and mobility of the inhabitants of enclaves of poverty, which have been identified, among others, on the basis of their drawings and sketch maps related to their place of residence: the yard, the nearest neighbourhood and the city. When constructing the model of attitudes, the author was inspired by Ludwik Stomma's ethnological description of world and anti-world and the levels of existential space distinguished by Christian Norberg-Schulz. The model includes: 1) imaginations and feelings towards specified spaces, by some seen as their own and tamed (orbis interior), while by others as foreign and wild (orbis exterior); and 2) spatial mobility, determined on the basis of spatial orientation (implosive, explosive) and spatial behaviour of the subjects (exploratory, escapist, and inertial).

M.N.

Dane Autorki:

dr hab. Marcjanna Nóżka, prof. UJ

Instytut Socjologii, Uniwersytet Jagielloński

ul. Grodzka 52, 31-044 Kraków

E-mail: marcjanna.nozka@uj.edu.pl

ORCID: 0000-0003-2637-760X 
